\section{Nursery Production of Uniola paniculata (southern seaoats)}

\author{
Gary R. Bachman and \\ Ted Whitwell ${ }^{2}$
}

Additional index words. container production, pine bark media, nutrition

Summary. Demand for commercially grown Uniola paniculata L. (southern seaoats) is increasing for use in restoring beaches damaged by tropical storms. Fresh seeds harvested from the Jekyll Island, Ga area (with permission of the Jekyll Island Authority), were planted in 50 peat: 50 perlite and treated with 100 or 500 ppm $\mathrm{GA}_{4}$ for $24 \mathrm{~h}$. Germination was higher for 100 compared to 500 ppm $\mathrm{GA}_{4}$. Liners grown from seed and planted with the crowns even with the surface of the pine bark-sand media, compared to deep planting to simulate burial conditions of beach planting, had the highest shoot and root weights after 100 days. Uniola paniculata liners with the crowns buried had reduced weights due to higher moisture conditions in the bottom of the containers. Uniola paniculata grown without supplemental fertilization had shoot weights similar to those of plants receiving $1.5 \mathrm{lb} \mathrm{N} / \mathrm{yd}^{3}\left(0.89 \mathrm{~kg} \mathrm{~N} / \mathrm{m}^{3}\right)$ from both quick or slow release fertilizers. Increasing $\mathrm{N}$ to $3 \mathrm{lb} / \mathrm{yd}^{3}$ $\left(1.78 \mathrm{~kg} \mathrm{~N} / \mathrm{m}^{3}\right)$ and/or supplying micronutrients only, reduced shoot weight. Nursery production of Uniola paniculata in pine bark-sand is one way to increase the supply of this important dune plant.

${ }^{1}$ Former graduate research assistant. Present address The Ohio State University 2001 Fyffe, Columbus, OH 43210.

${ }^{2}$ Professor, E-142 PEA Bldg, Box 340375, Clemson University, Clemson, SC 29634-0375

Technical contribution no. 4073 of the South Carolina Agricultural Experiment Station, Mention of a trademark, proprietary product, or vendor does not constitute a guarantee or warranty of the product and does not imply its approval to the exclusion of other products or vendors that may be suitable. The cost of publishing this paper was defrayed inpart by the payment of page charges. Under postal regulations, this paper therefore must be hereby marked advertisement solely to indicate this fact. niola paniculata (southern seaoats) is the dominant foredune building grass from southeastern Virginia along the Atlantic and Gulf coasts to eastern Mexico (Woodhouse and Hanes, 1966). This perennial grass has been used extensively to build artificial dunes and stabilize existing dunes. With the increased shoreline damage by tropical storms on the eastern seaboard in the last few years, the need for beach restoration-also has increased. Vegetative propagation for dune restoration in beach sand is expensive, and young plants are subjected to extreme environmental factors which can result in poor plant establishment and growth (Wagner, 1964). Direct seeding in the dunes is ineffective because of seed dormancy-viability and movement of sand which affects planting depth.

Uniola paniculata is not a prolific seed produce like many grasss. Typically panicles have many spikelets bearing 10 to 12 florets (Westra and Loomis, 1966). These are usually infertile at the terminal and distal ends, leaving 6 to 8 fertile florets, which produce fewer than 2 seeds per spikelet (Wagner, 1964). Sexual reproduction depends on wind dissemination of pollen. Successful pollination is affected by the florets opening and closing only once within a 24-h period (Colosi, 1979). High humidity and summer rain increase the incidence of fungal invasion. Aborted ovules in the florets have been observed to exhibit high infestations of Alterneria sp. and Helminthosporium sp. fungi which completely fill the floret with hyphae and conidia (Wagner, 1964).

The primary natural method of reproduction in the dune habitat is through vegetative means. Buds are formed around the stem base, and the formation angle of the buds determine whether shoot or lignified rhizomaceous tissue develops (Wagner, 1964). Acutely angled buds become tillers and right angled buds become rhizomes. Internodal potions of the rhizomes decay leaving the nodal regions with associated culms to root and become new plants. As sand is deposited around the base of the plant, these rhizomes establish roots in dune sand.

The dune habitat found along the coastal regions of the Southeast lacks sufficient nutrients for optimal growth (Wagner, 1964). Commercial nurser- ies in the Southeast commonly use pine bark-sand media, which is also nutrient-deficient (Wright and Niemiera, 1987). Nurseries attempt to maintain adequate nutrition by using quick-release granular fertilizer, controlled-release fertilizer or fertilizer injected into irrigation water, alone or in combinations. Macronutrient fertilizers commonly are applied to stimulate plant growth and increase vegetative cover in dune plantings (Woodhouse and Hanes, 1966)

Production of seeded Uniola paniculata in commercial nurseries would increase availability of plants for dune restoration. The objectives of this research were to 1 ) enhance germination of freshly harvested seed, 2) investigate the effect of planting depth within containers to simulate the dune environment, where the base of the plant is buried, and 3) determine an optimum nutrition program for Uniola panicuiata grown in pine bark-sand media for nursery production.

\section{Materials and methods}

Seed germination. Mature Uniola paniculata panicles were harvested from the Jekyll Island, Ga., area 15 Sept. 1993 in cooperation with the Jekyll Island Authority. The spikelets were rubbed over a screen to remove the chafe, and the seeds were collected. Harvested seeds were stored dry at $4 \mathrm{C}$ for 30 days. Before treatments all seed were soaked for $30 \mathrm{~min}$ in a $30 \%$ bleach solution as a surface sterilant. Seed treatments included 24h soak in 100 or 500 ppm gibberillic acid (GA4) or distilled water. Scarification also was applied to the seeds across all GA treatments. Seeds were scari fied using 600-grit sandpaper and gently rubbing the seeds between fingers. A scarified only and non-treated control also were included.

Seeds were planted in 40-cell trays using a standard nursery seed propagation media consisting of 1 peat moss : 1 perlite (by volume) and germinated in a shadehouse at Carolina Nurseries, Moncks Corner, S.C. Preplant fertilization for all treatments included incorporation of $9 \mathrm{lb} / \mathrm{yd}^{3}\left(5.34 \mathrm{~kg} \cdot \mathrm{m}^{-3}\right)$ $18 \mathrm{~N}-2.6 \mathrm{P}-9.9 \mathrm{~K}$ Osmocote and $9 \mathrm{lb} /$ $\mathrm{yd}^{3}\left(5.34 \mathrm{~kg} \cdot \mathrm{m}^{-3}\right)$ 14-7-7 granular fertilizer (Carolina Eastern-Malloy, Georgetown, S.C.). Apreplant drench of Banrot (O.M. Scotts Co., Marysville, Ohio) at $8 \mathrm{lb} / 100$ gal $(3.63 \mathrm{~kg} / 25.8$ liter) was applied. Seed were planted 1 
Table 1. Germination percentages of Uniola paniculata seeds as effected by preplant treatments.

\section{Seed treatment}

Germination percentage

Untreated control

100 ppm GA 4 soak

500 ppm GA $\mathrm{GA}_{4}$ soak

Distilled water soak

Scarification

Scarification + 100 ppm GA 4 soak

Scarification +500 ppm GA 4 soak

Scarification + Distilled water soak

${ }^{2}$ Treatments analyzed using least significant difference (LSD) mean separation. Column means with the same letter are not different based on $P=0.05$.

inch $(2.5 \mathrm{~cm})$ deep with two seeds per cell. Treatments were arranged in a randomized complete block design (RCBD) with five blocks of each seed treatment and five replicate cells per block.

The 40-cell trays were irrigated by mist for 5 min initially followed by mist every $16 \mathrm{~min}$ for $8 \mathrm{sec}$ during the first 10 days and then every $32 \mathrm{~min}$ for $8 \mathrm{sec}$ for the remainder of the study. The study was started on 17 Nov. 1993 and concluded 20 Dec. 1993. On 20 Dec. 1993, germination percentages were determined for the seed treatments. Analysis of variance and least significant difference determined, if $\mathrm{F}$ test was significant at $P=0.05$, were performed on all data.

A follow-up study was conducted in a glass greenhouse at Clemson University. Seeds collected at Jekyll Island and stored at $4 \mathrm{C}$ for 136 days were planted in a peat-based medium, Fafard no. 3B (Fafard, Anderson, S.C.). Two planting depths were studied, 0.5 and 1 inch $(1.25$ and $2.5 \mathrm{~cm})$. Seeds were given preplant treatments consisting of a control and 24-h soaks in distilled water, $100 \mathrm{ppm}\left(\mathrm{mg} \cdot\right.$ liter $\left.^{-1}\right)$ gibberillic acid $\left(\mathrm{GA}_{4}\right)$, and $7 \mathrm{~mm}$ and $14 \mathrm{~mm}$ thiourea. There were four replications of each seed treatment $\times$ planting depth combination with five cells per replicate. On 8 Feb 1994, before planting, all seeds were disinfected by immersing in $30 \%$ bleach solution for 30 rein, and the medium was drenched with Banrot at $8 \mathrm{lb} / 100$ gal $(3.63 \mathrm{~kg} / 5.8$ liter). The seeds were planted in a $200-$ cell plug tray with two seeds per cell. The plug tray was placed under mist at an interval of $8 \mathrm{~min}$ for $8 \mathrm{sec}$. Bottom heat was provided at a constant temperature of $25 \mathrm{C}$. The study was begun 9 Feb. 1994 and terminated 9 Mar. 1994.

Planting depth. Well rooted seed-grown liners of Uniola paniculata were planted in a 4 pine bark : 1 sand (by volume) media on 15 Mar. 1994 at Carolina Nurseries. Two containerizes were used: 3.8 liter $(19 \mathrm{~cm}$ diameter $\times$ $17.8 \mathrm{~cm})$ and 9.2 liter $(20.3 \mathrm{~cm}$ diameter $\times 38.1 \mathrm{~cm})$, full l-gal and 3-gal tree containers respectively. The liners were placed in the 3.8-liter containers with the crown either even with the surface of the media or 4 inches (10 $\mathrm{cm}$ ) below the media surface. Liners were planted in the 9.2-liter containers with the crown also 4 inches (10 $\mathrm{cm})$ below the media surface. The bottom of the deeply planted liners were either on the bottom of the 3.8liter container or $20 \mathrm{~cm}$ above the container bottom for the 9.2 -liter container. Treatments were arranged in a RCBD with five blocks per container treatment. The plants were topdressed with $16 \mathrm{~g}\left(0.89 \mathrm{~kg} \cdot \mathrm{m}^{-3}\right)$ of $18-3-6+$ $\mathrm{Mg}$ Osmocote Custom Blend (O.M. Scotts Co., Marysville, Ohio) and grown outside. Irrigation was applied using overhead sprinklers following normal nursery practice of $12.5 \mathrm{~mm}$ of water per day.

On 6 July 1994, the study was terminated. Shoots and roots were collected and dried at $60 \mathrm{C}$ for 5 days and dry weight determination of both shoot and root tissue and root: shoot ratio were determined.

Nutrition. Well rooted seedgrown liners of Uniola paniculata were same letter are not different based on $\mathrm{P}=0.05$. planted in a 4 pine bark :1 sand (by volume) media on 15 Mar. 94 at Carolina Nurseries. The plants were planted with the crowns even with the top of the media in trade 1-gal (2.8-liter) containers. Fertilizers were applied at standardized rates of nitrogen, 1.5 or $3 \mathrm{lb} \mathrm{N} / \mathrm{yd}^{3}\left(0.89\right.$ or $\left.1.78 \mathrm{~kg} \mathrm{~N} / \mathrm{m}^{3}\right)$, on 5 Apr. 1994. The containers were topdressed with the following nursery fertilizer formulations: 1) 14-7-7 with micronutrients granular quick release formulation (16.2 or $32.4 \mathrm{~g} / \mathrm{con}$ tainer), 2) 18-3-6 with micronutrients Osmocote Custom Blend slow release (12.6 or $25.2 \mathrm{~g} /$ container), 3 ) 16-7-12 without micronutrients Osmocote slow release (14.2 or $28.4 \mathrm{~g} /$ container), or 4) STEP micronutrients $2 \mathrm{lb} / \mathrm{yd}^{3}$ STEP (3 g/container) (a complete micronutrient formulation from O.M. Scotts Co.). The control was not topdressed with additional fertilizer, however it did receive the normal nursery practice of twice weekly fertilizer-injected irrigation, which contained 1.28 mol-liter $\mathrm{Mg}\left(\mathrm{N} \mathrm{O}_{3}\right)_{2} \cdot 2 \mathrm{H}_{2} \mathrm{O}, 3.80 \mathrm{~mol} \cdot$ liter $^{-1}$ $\mathrm{KNO}_{3}$, and $0.96 \mathrm{~mol} \cdot \mathrm{liter}^{-1} \mathrm{~K}_{2} \mathrm{HPO}_{4}$. Treatments were arranged in a RCBD with five blocks per container treatment. Irrigation was applied using overhead sprinklers following normal nursery practice of $12.5 \mathrm{~mm}$ of water per day.

The study was terminated on 7 July 1994. Shoot tissue was removed and dried for weight determination. Tissue nutrient levels were measured from the uppermost recently developed leaves which were weighed and included in the dry weight.

\section{Results and discussion}

Seed Germination. Seeds soaked in 100 ppm GA had the highest germination percentages 21 days after treatment (DAT) (Table 1). At 21 DAT the emerged seedlings from the 100 ppm GA treatment were judged to be most desirable. Seedlings from the 500 ppm GA $_{4}$ treatment were

Table 2. Shoot dry weight, root dry weight, and root/shoot ratio of Uniola paniculata grown under different planting depths in a 4 pine bark: 1 sand (by volume) media.

\begin{tabular}{lccc}
\hline Depth treatment & $\begin{array}{c}\text { Shoot } \\
\text { dry wt }(\mathrm{g})\end{array}$ & $\begin{array}{c}\text { Root } \\
\text { dry wt (g) }\end{array}$ & $\begin{array}{c}\text { Root/shoot } \\
\text { ratio }\end{array}$ \\
\hline 3.8-liter (Crown even with media surface) & $157 \mathrm{a}^{\mathrm{z}}$ & $24.2 \mathrm{a}$ & $0.15 \mathrm{a}$ \\
3.8-liter (Crown $10 \mathrm{~cm}$ below media surface) & $106 \mathrm{~b}$ & $14.3 \mathrm{~b}$ & $0.15 \mathrm{a}$ \\
9.2-liter (Crown 10 cm below media surface) & $144 \mathrm{a}$ & $12.2 \mathrm{~b}$ & $0.08 \mathrm{a}$
\end{tabular}

"Treatments analyzed using least significant difference (LSD) mean separation, Column means with the 
Table 3. Results of tissue analysis ${ }^{2}$ and shoot dry weight of container-grown Uniola panicolata treated with various fertilizer formulations at standardized rates of 1.5 or $3 \mathrm{lb} \mathrm{N} / \mathrm{yd} \mathrm{d}^{3}\left(0.89\right.$ or $\left.1.78 \mathrm{~kg} \mathrm{~N} / \mathrm{m}^{3}\right)$ in a 4 pine bark: 1 sand (by volume) media.

\begin{tabular}{|c|c|c|c|c|c|c|c|c|c|c|c|}
\hline Fertilizer & $\mathrm{g} /$ container & $\mathrm{Wt}(\mathrm{g})$ & $\mathbf{N}$ & $\mathbf{P}$ & $\mathbf{K}$ & $\mathrm{Ca}$ & $\mathbf{M g}$ & $\mathrm{Fe}$ & Mn & $\mathrm{Cu}$ & $Z_{n}$ \\
\hline Control & $---y$ & $60.4 \mathrm{ab}^{\mathrm{x}}$ & $1.47 \mathrm{c}$ & $1.10 \mathrm{~b}$ & $1.20 \mathrm{e}$ & $0.33 \mathrm{ab}$ & $0.12 \mathrm{ab}$ & $54.2 \mathrm{bc}$ & $31.0 \mathrm{c}$ & $3.2 b c$ & $9.2 \mathrm{~b}$ \\
\hline $14-7-7$ & 16.2 & $61.2 \mathrm{ab}$ & $1.67 \mathrm{ab}$ & $0.13 \mathrm{ab}$ & $1.39 b c$ & $0.34 \mathrm{ab}$ & $0.13 \mathrm{ab}$ & $62.2 \mathrm{ab}$ & $47.0 \mathrm{ab}$ & $4.2 \mathrm{a}$ & $13.6 \mathrm{ab}$ \\
\hline $14-7-7$ & 32.4 & $30.5 \mathrm{c}$ & $1.55 b c$ & $0.11 \mathrm{~b}$ & $1.25 \mathrm{e}$ & $0.28 \mathrm{~b}$ & $0.11 \mathrm{~b}$ & $59.0 \mathrm{ab}$ & $55.6 \mathrm{a}$ & $3.4 \mathrm{abc}$ & $10.8 \mathrm{ab}$ \\
\hline $16-7-12$ & 14.2 & 79.9 a & $1.45 \mathrm{c}$ & $0.10 \mathrm{~b}$ & $1.33 \mathrm{~cd}$ & $0.37 \mathrm{ab}$ & $0.16 \mathrm{a}$ & $55.2 \mathrm{bc}$ & $39.6 \mathrm{bc}$ & $3.6 \mathrm{ab}$ & $12.8 \mathrm{ab}$ \\
\hline $16-7-12$ & 28.4 & $24.7 \mathrm{c}$ & $1.69 \mathrm{ab}$ & $0.16 \mathrm{a}$ & $1.36 \mathrm{bcd}$ & $0.50 \mathrm{a}$ & $0.16 \mathrm{a}$ & $67.2 \mathrm{a}$ & $37.8 b c$ & $4.0 \mathrm{ab}$ & $18.0 \mathrm{a}$ \\
\hline $18-3-6$ & 12.6 & $77.5 \mathrm{a}$ & $1.77 \mathrm{a}$ & $0.12 \mathrm{ab}$ & $1.51 \mathrm{a}$ & $0.30 \mathrm{~b}$ & $0.14 \mathrm{ab}$ & $56.2 \mathrm{bc}$ & $35.4 \mathrm{bc}$ & $2.6 c$ & $12.6 \mathrm{ab}$ \\
\hline $18-3-6$ & 25.2 & $48.5 \mathrm{ab}$ & $1.80 \mathrm{a}$ & $0.13 \mathrm{ab}$ & $1.45 \mathrm{ab}$ & $0.28 \mathrm{~b}$ & $0.15 \mathrm{ab}$ & $59.2 \mathrm{ab}$ & $53.0 \mathrm{a}$ & $3.8 \mathrm{ab}$ & $17.0 \mathrm{a}$ \\
\hline Micros & 3.0 & $34.5 \mathrm{c}$ & $1.44 \mathrm{c}$ & $0.11 \mathrm{~b}$ & $1.32 \mathrm{~cd}$ & $0.24 \mathrm{~b}$ & $0.11 \mathrm{~b}$ & $48.2 \mathrm{c}$ & $36.4 \mathrm{bc}$ & $3.2 b c$ & $11.8 \mathrm{ab}$ \\
\hline
\end{tabular}

${ }^{2}$ Results expressed as percentage for macronutrients $(\mathrm{N}, \mathrm{P}, \mathrm{K}, \mathrm{Ca}, \mathrm{Mg})$ and $\mathrm{ppm}$ for micronutrients $(\mathrm{Fe}, \mathrm{Mn}, \mathrm{Cu}, \mathrm{Zn})$.

${ }^{y}$ The control was not topdressed with additional fertilizer, however did receive the normal nursery practice of twice weekly fertilizer-injected irrigation which contained 1.28 mol.liter $\mathrm{Mg}\left(\mathrm{NO}_{3}\right) \cdot 2 \mathrm{H}_{2} \mathrm{O}, 3.80$ mol.liter $\mathrm{KNO}_{3}$, and 0.96 mol.liter $\mathrm{K}_{2} \mathrm{HPO}_{4}$

${ }^{x}$ Treatments analyzed using mean separation. Column means $w$ ith $M$ the same letter are not different based on $P=0.05$ using least significant difference (LSD).

twisted, caused by excessive cell elongation (Taiz and Zeiger, 1991 ). Scarified seeds were observed to have had swelling equivalent to treatments that received soaking treatments only; however, scarification was not necessary to promote germination and resulted in germination no better than the control.

In the follow-up study there was no difference in the germination rates of any of the treatments (data not shown). The germination rate of the 100 ppm GA $_{4}$ soak was lower than previously observed. Thiourea did not improve the germination percentage, although it has been used effectively by other researchers to stimulate germination of seeds that require a moistchilling treatment (Hartmann and Kester, 1983). Westra and Loomis (1966) reported thiourea had no effect on germination in petri dishes, but at $7 \mathrm{~mm}$ thiourea dramatically increased Uniola seed germination in sand.

Westra and Loomis ( 1966) found that as storage time increased germination decreased, showing either increased dormancy or decreased viability and that storage time is an important consideration. Soaking in $100 \mathrm{ppm}$ $\mathrm{GA}_{4}$ increased and accelerated germination of freshly harvested seed, and as storage time increased, germination rate was reduced. Our data supports the use of a $\mathrm{GA}_{4}$ soak. It appears that Uniola paniculata has a short span of seed viability in storage and that seed dormancy was not the cause of poor germination.

Planting depth. Planting depth did have a significant influence on shoot growth (Table 2). Plants grown with the crown even with the media surface in 3.8-liter or deep in 9.2-liter containers had higher shoot weights than plants grown deep in 3.8-liter containers. Root dry weights also were affected by planting depth, the plants grown deep had the lowest root weights. Root to shoot ratios were similar between the planting depths. However, plants grown in the 3.8-liter containers, regardless of planting depth, had root/shoot ratios almost twice as high as the plants grown in the 9.2-liter containers.

Although the root/shoot ratios of the plants grown in 3.8-liter containers were similar, there were differences in the weights of the dried shoot and root. The reason for these differences can be related back to the planting depth. Plants grown in the bottom of these containers are exposed to a perched water table or zone of media saturation. The media in containers remains wet under a regime of regular irrigation such as would be followed in a commercial nursery in the Southeast. Hester and Mendelssohn (1989) found that seaoats growing in a natural dune setting and also under controlled experimentation reacted adversely to waterlogging stress. In experiments in which the root zones were placed at decreasing heights above the water table, Hester and Mendelssohn ( 1989) demonstrated that excessive soil moisture resulted in reduced biomass production. However, decreasing soil moisture did not stimulate increased growth.

Nutrition. Levels of tissue nutrients were similar were similar in many cases (Table 3). However, there were significant effects on shoot dry weights due to fertilizer rate. The control treatment and the low $\mathrm{N}$ rates had higher shoot weights compared to the high $\mathrm{N}$ rates for each formulation (Table 3 ). As $\mathrm{N}$ rate increased to $3 \mathrm{lb} /$ $\mathrm{y} \mathrm{d}^{3}$, however the amount of shoot biomass decreased for all three fertilizer formulations. The micronutrientonly treatment also resulted in lower shoot weight. Hester and Mendelssohn (1990) also found that micronutrients, either alone or in combination with macro nutrients, had negatively correlated effects on growth parameters of $U$. paniculata. In our study doubling the rate of fertilizer application not only increased the amount of macronutrients but also the micronutrients, if treatment was a complete formulation.

\section{Conclusions}

Uniola paniculata has the potential to become a widely grown nursery plant in the Southeast. Seeds should be planted soon after harvest in the fall to ensure highest germination percentages of these seeds. A GA 4 preplant soak of the seeds will help more rapid and uniform germination. The longer harvested seeds are held in storage, decreased viability lowers germination efficiency.

Typically on the dunes, the crowns of $U$. paniculata become buried by drifting sand, however, burying the crown of $U$. paniculata in 3.8-liter containers reduced the shoot and root weight of the plant due to the increased moisture in the bottom of the containers. Reducing the frequency and amount of irrigation would be helpful in encouraging maximum growth.

Finally, U. paniculata does not respond like most plants grown in containers to increased nutrient inputs. High fertilization rates, whether 


\section{RESEARCH UPDATES}

granular or controlled release, dramatically reduced the shoot weight of the plant. Nutrient inputs should be maintained at a minimum.

The results of these experiments suggest that, through proper management, $U$. paniculata potentially could be a successful crop for nurseries to grow.

\section{Literature Cited}

Colosi, J. C. 1979. Seed germination as a function of provenance in Iva imbricata and Uniola paniculata, two wide-ranging coastal dune dominants. PhD diss. N.C. State Univ.

Hartmann, H. T. and D.E. Kester. 1983. Techniques of propagation by seeds, $\mathrm{p}$. 177. In: Plant propagation principles and practices. 4th ed. Prentice-Hall, Englewood Cliffs, N.J.

Hester, M. W. and I.A. Mendelssohn. 1989. Water relations and growth responses of Uniola paniculata (sea oats) to soil moisture and water-table depth. Oecologia 78:289-296.

Hester, M. W. and I.A. Mendelssohn. 1990. Effects of macronutrient and micronutrient additions on photosynthesis, growth parameters, and leaf nutrient concentrations of Uniola paniculata and Panicun amarum. Bot. Gaz. 151(1):21-29.

Taiz, L. and E. Zeiger. 1991. Plant physiolow. 1st ed. Benjamin/Cummings Pub lishing Co., Redwood City, Calif.

Wagner, R.H. 1964. The ecology of Uniola paniculata L. in the dune-strand habitat of North Carolina. Ecol. Monogr. 34:79-96.

Westra, R.N. and W.L. Loomis. 1966. Seed dormancy in Uniola paniculata. Amer. J. Bet. 53(4):407-411.

Wright, R.D. and A.X. Niemiera. 1987. Nutrition of container-grown woody nursery crops. Hort. Rev. 9:75-101 .p

Woodhouse, W. W., Jr., and R.E. Hanes. 1966. Dune stabilization and vegetation on the Outer Banks of North Carolina. Soil Sci. Ser. 8. N.C. State Univ., Raleigh. 